\title{
International open innovation and international market success: an empirical study of emerging market small and medium-sized enterprises
}

\author{
Nadia Zahoor \\ Hunter Centre for Entrepreneurship, University of Strathclyde, Glasgow, UK \\ Zaheer Khan \\ Business School, University of Aberdeen, Aberdeen, UK \\ Ahmad Arslan \\ Department of Marketing, Management and International Business, \\ University of Oulu, Oulu, Finland \\ Huda Khan \\ Business School, University of Aberdeen, Aberdeen, UK, and \\ Shlomo Yedidia Tarba \\ Department of Strategy and International Business, University of Birmingham, \\ Birmingham, UK
}

\begin{abstract}
Purpose - This paper presents a theorization and an empirical analysis of the influences of international open innovation (IOI) on the international market success of emerging market small and medium-sized enterprises (ESMEs). An analysis of the moderating roles played by cross-cultural competencies and digital alliance capabilities in this specific context is also presented.

Design/methodology/approach - The study adopted a quantitative research design involving a survey of 231 ESMEs based in the UAE. The authors formulated some hypotheses and tested them by employing hierarchical regression models.

Findings - The findings revealed that IOI positively affects the international market success of ESMEs. The authors further found that both cross-cultural competencies and digital alliance capabilities moderate the relationship between IOI and international market success.

Originality/value - The study advances the international marketing, knowledge and innovation management literature in two ways. First, it is a pioneering study that advances both the theoretical and empirical scholarship regarding the relationship between IOI and emerging market firm international market success by employing an extended resource-based view. Second, it further highlights the role played by cross-cultural competencies and digital alliance capabilities as effective governance mechanisms that moderate the relationship between IOI and international market success.
\end{abstract}

Keywords Cross-cultural competencies, Digital alliance capabilities, Emerging market, International open innovation, International market success, SMEs, Resource-based view

Paper type Research paper

(C) Nadia Zahoor, Zaheer Khan, Ahmad Arslan, Huda Khan and Shlomo Yedidia Tarba. Published by Emerald Publishing Limited. This article is published under the Creative Commons Attribution (CC BY 4.0) licence. Anyone may reproduce, distribute, translate and create derivative works of this article (for both commercial and non-commercial purposes), subject to full attribution to the original publication and authors. The full terms of this licence may be seen at http://creativecommons.org/licences/by/4.0/ legalcode
International open innovation for market success

Received 31 December 2020 Revised 26 March 2021 7 May 2021

Accepted 18 June 2021 
IMR

39,3

\section{Introduction}

Over the past few decades, small and medium-sized enterprises (SMEs) have become important players in the international business landscape (Oehme and Bort, 2015; Paul and Rosado-Serrano, 2019; Sui and Baum, 2014). This is particularly true of SMEs from developed countries, which usually possess country-specific competitive advantages (e.g. technological advancement and efficient transportation and communication) that they quickly utilize and transpose to international markets (Del Giudice et al., 2017; D’Angelo et al., 2016; Li et al., 2018). Conversely, emerging market SMEs (ESMEs) are often characterized by weak home-based competitive attributes when doing business internationally (Scuotto et al., 2020b; Xiao et al., 2020). By definition, ESMEs are characterized by liabilities of newness and emergingness, which result in them lacking a competitive edge over their rivals in the international marketplace (Rahman et al., 2017; Zhang et al., 2014). Thus, compared with their competitors from advanced economies, ESMEs are often at a disadvantage in regard to achieving international market success due to their lack of technical knowledge and skills (Khan and Lew, 2018; Puthusserry et al., 2020). Despite the increasing prominence of ESMEs, little is known about what drives their international market success in competitive marketplaces, which is illustrated by their rapid expansion into foreign markets.

Scholars have demonstrated the importance of international strategic alliances in driving SME international market success (Kafouros and Forsans, 2012; Li et al., 2017). Such alliances provide access to valuable knowledge and help to co-create idiosyncratic resources suited to the achievement of economic success and international competitiveness (Ferreras-Méndez et al., 2019; Musteen et al., 2014; Sheng and Hartmann, 2019). In addition, the innovation literature recognizes that the establishment of ties with international partners facilitates the development of innovation (Romero-Martínez et al., 2017), which is vital for international market success. Specifically, increasing attention has been paid to open innovation (OI), which refers to the "use of both inflows and outflows of knowledge to improve internal innovation and expand the markets for external exploitation of innovation" (Cheng and Huizingh, 2014, p. 1235). OI is also defined as "distributed innovation process based on purposely managed knowledge flows across organizational boundaries, using pecuniary and non-pecuniary mechanisms in line with the organization's business model" (Chesbrough and Bogers, 2014, p. 1). By embracing OI with various stakeholders, SMEs can gain various benefits - including risk reduction, timely entry into international markets and innovation performance (Albats et al., 2020; Nordman and Tolstoy, 2016). While assuming that OI is beneficial to the international efforts of large firms (Naqshbandi and Jasimuddin, 2018), only scant prior research has hitherto examined the OI and international competitiveness of ESMEs (cf. De Silva and Wright, 2019; Martínez-Román et al., 2019). Furthermore, the OI strategies adopted by firms differ considerably, as some engage in it domestically, whereas others do so internationally (Leckel et al., 2020). Domestic and international OI strategies exert differing influences on the types of external knowledge and outcomes in relation to value creation (Kafouros and Forsans, 2012). The OI literature has rarely differentiated between the domestic and international search for knowledge. Specifically, most scholarly attention has been devoted to the significance of domestic OI for SME international competitiveness (Santoro et al., 2019), neglecting international open innovation (IOI), which is nevertheless an important research area, particularly in the context of resource-constrained ESMEs that are rapidly internationalizing.

Our study was, therefore, focused on the nexus between IOI and international market success. This can be considered important for ESMEs for two reasons. First, ESMEs have fewer competitive resources and capabilities in terms of technology, international marketing competencies and financial resources, which hinders their success in both the domestic and foreign markets; therefore, they need to be open to the establishment of network partnerships with international counterparts not only to innovate (Bhatti et al., 2021; Soto-Acosta et al., 2018), 
but also to achieve international competitiveness (Scuotto et al., 2020b). Second, the lack of commercial assets and the weak institutional context found in emerging markets (EMs) encourage ESMEs to explore IOI to achieve international market gains (Radulovich et al., 2018). Accordingly, by drawing insights from the extended resourcebased view (extended RBV), our study considered the importance of IOI for the international market success of ESMEs. Furthermore, we argued for the existence of boundary conditions for the relationship between IOI and international market success. Specifically, we zoomed in on two key moderators - cross-cultural competencies and digital alliance capabilities. First, we considered the moderating role of cross-cultural competencies. Given that IOI is a complex and costly process - which requires close coordination between knowledge exchange partners - cross-cultural competencies is likely to reduce any ambiguity found in the knowledge-exchange process (Basuil and Datta, 2015). Second, digital alliance capabilities facilitate the communication and coordination of OI activities through information and communication technologies (ICTs) (Urbinati et al., 2020), which include "electronic communication tools (e.g. email, instant messaging, voice mail, faxing, and paging), electronic conferencing tools (e.g. data conferencing, voice conferencing, videoconferencing, discussion forums, and chat systems), collaborative work management tools (e.g. file sharing and group calendars), and social networking tools (e.g. Facebook, Yammer, and Chatter)" (Oldham and Silva, 2015, p. 7). By exploiting their digital alliance capabilities, ESMEs can influence the level of joint dependency, remain connected with their international partners and transform the structure of their international relationships (Cherbib et al., 2021). In fact, digital alliance capabilities enable partners to connect easily with each other, learn more and achieve their mutual objectives (He et al., 2020). Such capabilities can further support the co-creation of opportunities for innovation and ESME international market success. Therefore, it is important to understand the role played by digital alliance capabilities in facilitating IOI and the international market success of ESMEs.

Thus, our study was aimed at answering the following two interrelated questions: "What is the relationship between IOI and the international market success of ESMEs?" and "What are the impacts of cross-cultural competencies and digital alliance capabilities on the relationship between IOI and the international market success of ESMEs?" To answer these questions, we leveraged a unique primary survey involving 231 ESMEs originating from the UAE, which has been referred to as a very good and rather underexplored context for such type of research (e.g. Elbanna and Fadol, 2016; Genc et al., 2019).

Our study makes three important contributions to the extant literature. First, it extends the international marketing and OI literature by suggesting that IOI provides ESMEs with resources and competencies suited to the development of innovative products that meet their global customers' needs; this, in turn, will enhance their international market success. Diverging from most prior studies, which emphasized domestic OI for innovation and financial performance (Leckel et al., 2020; Popa et al., 2017), this finding provides empirical evidence that IOI impacts the international market success of ESMEs. Second, the literature on international marketing suggests that international alliances entail risks in terms of the competencies required to effectively manage them and utilize the resources embedded in alliance networks (Kamalaldin et al., 2020; Kohtamäki et al., 2018). Thus, this study integrated two important moderating factors leading to international market success - cross-cultural competencies and digital alliance capabilities - as critical aspects of knowledge capabilities in this context. Third, our study adds to the limited literature on the international market success of ESMEs. Particularly, we drew our data from the UAE, which, due to its numerous smaller private firms, is among the most relevant contexts for this kind of research (e.g. Genc et al., 2019). As private ESMEs are at a disadvantage compared to their state-owned counterparts in regard to accessing valuable resources at home and achieving institutional support (Nakos et al., 2019; Pervan et al., 2015), leveraging IOI might be an important 
IMR

39,3

alternative for them to overcome their home market resource constraints and achieve international market success.

Besides contributing to knowledge, our study has practical and policy implications. First, it provides ESME managers with a new approach to innovation by highlighting the importance of international alliances and networks. Specifically, ESMEs can engage in IOI to overcome any issues linked to limited resource availability and lack of institutional support found in their domestic markets. By engaging in IOI, ESMEs can gain new knowledge and promote learning conducive to international market success. Second, our study demonstrates that ESMEs need to acknowledge and consider digital alliance capabilities to virtually coordinate and communicate their IOI activities with their network partners. ESMES should invest in the development of those digital alliance capabilities that can influence the quality of their IOI and, in turn, determine their international market success. Third, our study highlights the relevance of cross-cultural competencies in ensuring that managers perform IOI activities effectively to promote international market success. Thus, ESMEs need to offer their managers cross-cultural training and simulations to promote their cultural learning opportunities. Our findings also provide important insights to EM policy makers, who - as they are keen to develop their economies and promote the internationalization of small firms need to provide institutional support and facilitate the exposure of such firms to international networks (e.g. though their participation in trade fairs), to enable them to leverage those networks for knowledge and develop their capabilities. Policy makers could also provide special incentives - such as vouchers for innovation - to those small firms that are rapidly expanding into foreign markets and utilizing international sources of knowledge. Finally, policy makers could also support small firms by identifying and connecting them to any relevant international sources of knowledge and innovation.

\section{Theoretical background and hypotheses development}

\subsection{International open innovation and the extended resource-based view}

Over the decades, the RBV has been one of the dominant frameworks emphasizing a firm's internal resources as the primary means for the development of competitive advantage (Barney, 1991). Amit and Schoemaker (1993) described such resources as the "stocks of available factors that are owned and controlled by the firm" (p. 35). The conventional RBV has been criticized because of its under-emphasis of the role played in shaping competitive advantage by the external resources entrenched in strategic alliances (Arya and Zhiang, 2007; Mahoney, 2001). Against this backdrop, a growing research stream is extending the RBV (Dyer and Singh, 1998; Lavie, 2006), whereby the complementary resources attained through external partners are also sources of a firm's competitive advantage (Gulati, 2007). This extended RBV suggests that external alliance resources provide strategic opportunities for the acquisition of a partner's knowledge resources - which, in turn, are conducive to the development of competitive positioning (Paul and Rosado-Serrano, 2019). Thus, building on the logic of the extended RBV (Arya and Zhiang, 2007; Lavie, 2006), our study highlights external network resources as a source of competitive advantage for firms.

International marketing research suggests that, compared with large multinationals, internationalizing ESMEs possess limited financial and knowledge resources suited to act as sources of competitive advantage (Khan and Lew, 2018; Puthusserry et al., 2020). Furthermore, ESMEs are often private firms and experience latecomer difficulties i.e. they lack the competitive and managerial resources and capabilities (Wang et al., 2014; Xiao et al., 2021) that are vital to attain a competitive positioning in the international marketplace. Hence, ESMEs need to set up strategic alliances with international partners and engage in costly innovation activities to overcome their home market disadvantages, such as their lack of resources and capabilities (Del Giudice et al., 2019; Sandberg, 2014). 
This is consistent with the extended RBV, which suggests that, to a great extent, the nature and type of any external alliances determine and signify their value and uniqueness (Ireland et al., 2002; Rauch et al., 2016), meaning that not all strategic alliances have the same implications for international market success (Abdelbadie and Salama, 2019; Xiao et al., 2021). Accordingly, by drawing on the extended RBV, our study provides an explanation for the ways in which these firms remedy their resource and capability voids by relying on international strategic alliances. In this regard, we argued that IOI constitutes a differentiating factor in regard to the degree of international market success achieved by ESMEs. Generally, IOI is a model that describes the ways in which firms innovate by soliciting ideas from or sharing internal resources with international alliance partners (Chesbrough, 2006; Chesbrough et al., 2018). As such, it involves two prominent categories: inbound and outbound innovation. Inbound innovation refers to the inflow of knowledge and inputs from external partners aimed at facilitating innovation (Jasimuddin and Naqshbandi, 2019), whereas outbound innovation relates to leveraging of internal resources and knowledge to external partners by licensing and forming alliances suited to generate value (Bellantuono et al., 2013). A large body of IOI research has focused on large multinational firms, which possess the resources and capabilities necessary to benefit from external networks (Li and Kozhikode, 2009; Mortara and Minshall, 2011; Naqshbandi and Jasimuddin, 2018). Lately, growing scholarly attention has been devoted to domestic OI in the context of SMEs (Martinez-Conesa et al., 2017; Popa et al., 2017). For example, Freixanet et al. (2020) recently examined the influence of international entrepreneurial orientation as a key antecedent of $\mathrm{OI}$ and of social media as a mediator between $\mathrm{OI}$ and innovation performance. Furthermore, Hameed et al. (2021) suggested that external knowledge and internal innovation influence OI performance in a domestic context (Pakistan). Although research has emphasized on IOI (Brem and Nylund, 2021), to date, how engaging in it benefits the international market success of ESMEs remains unclear. We posited that IOI supports ESMEs in overcoming any home market constraints and in adapting to globally competitive environments. Thus, IOI promotes new technological and organizational knowledge (Romero-Martínez et al., 2017; Santoro et al., 2018), while also increasing ESME international market success (Musteen et al., 2014).

The scholarship suggests that engaging in IOI results in complexities relating to the need to adapt to cultural differences, which may limit the value-generating potential of external relationships (Elia et al., 2019; Ojala, 2009; Peeters et al., 2015). Furthermore, any cultural differences between alliance partners affect the ways they interact, exchange knowledge and learn from each other (López-Duarte et al., 2016). Unlike domestic partnerships, international alliances face problems of "double layered acculturation" (Barkema et al., 1996, p. 154), which may "inhibit the informal chemistry that is essential for coordination and ongoing conflict resolution in alliances" (Lavie and Miller, 2008, p. 626). Accordingly, Kujala and Törnroos (2018) suggested that ESMEs should pay attention to the influence of IOI strategies and consider maintaining and developing relationships in ways that are mutually beneficial. Thus, our study attempted to examine how an ESME's cross-cultural competencies and digital alliance capabilities affect the relationship between IOI and international market success. We suggested that those ESMEs that engage in IOI will perform better in achieving international market success if they possess the cross-cultural competencies and digital alliance capabilities needed to build and maintain successful external partnerships for value creation. These arguments are consistent with those found in the extant literature, which recommends that OI involves a diverse and wide range of distributed network collaborators, also in terms of ecosystems and platforms (West, 2014). Against this backdrop, digital technologies such as open-source software and virtual innovation competition - play a vital role in facilitating such collaborations (Ebner et al., 2009); thus, cross-cultural competencies and 
IMR

39,3

760

digital alliance capabilities take central stage in regard to enhancing value through IOI for ESMEs.

The following sections examine the role played by IOI for ESME international market success. Furthermore, we provide arguments related to the moderating role played by cross-cultural competencies and digital alliance capabilities in the IOI-international market success relationship. Figure 1 shows the conceptual model and hypotheses of this study.

\subsection{International open innovation and international market success}

In general, OI is beneficial for firm performance (Carayannis and Grigoroudis, 2014; Singh et al., 2019). For example, Popa et al. (2017) suggested that OI effectiveness can lower costs, increase sales and enhance technological positions. In this case, SMEs had become involved in OI with domestic partners to the end of sharing benefits. However, increased globalization and dynamic environments call for the diversification of sources of knowledge and the sharing of ideas with international alliance partners (Xiao et al., 2021). OI differs for SMEs and large firms mainly due to the different contributions it makes to their competitiveness (Lee et al., 2010). To understand the influence of OI on SMEs, we considered the context of the UAE, which has been quite successful in establishing a strong presence in the business industry and implementing major reforms (UAE, 2013). The knowledge capacity of the UAE has grown substantially by relying on foreign partners and government support for innovation (Pervan et al., 2015). There have been mass projects - such as Dubai Media City, Internet City, etc. - in which SME firms were able to collaborate and interact with one another for OI. Moreover, scholars argue that SMEs can enhance their performance through OI by expanding beyond their institutional boundaries (Pervan et al., 2015). However, local sources of knowledge may not be sufficient to support SMEs in exploiting international opportunities, given that the valuable knowledge required resides across distributed global networks. Therefore, IOI plays an important role in enabling firms to develop a competitive advantage (Guo and Zheng, 2019), including international market success.

First, prior empirical research suggests that knowledge creation and diffusion are localized and spatially bound (Almeida and Kogut, 1999). This geographical constraint can limit an ESME's ability to benefit from any externalities arising from knowledge in different international markets (Kafouros and Forsans, 2012). IOI may assist ESMEs in accessing a variety of knowledge generated in different marketplaces, thereby boosting innovation and facilitating international market success (Musteen et al., 2014). This is particularly true in the context of EMs, such as the UAE, which lack in-house sophisticated knowledge and technologies. Scholarship suggests that EM firms benefit from international networks in developing innovations (cf. Khan et al., 2018). IOI also enables ESMEs to achieve international market success by exploiting their existing knowledge and technologies in the global marketplace, yet minimizing the risks linked to obsolescence to remain competitive (Singh et al., 2019).

Figure 1.

The conceptual framework of our study

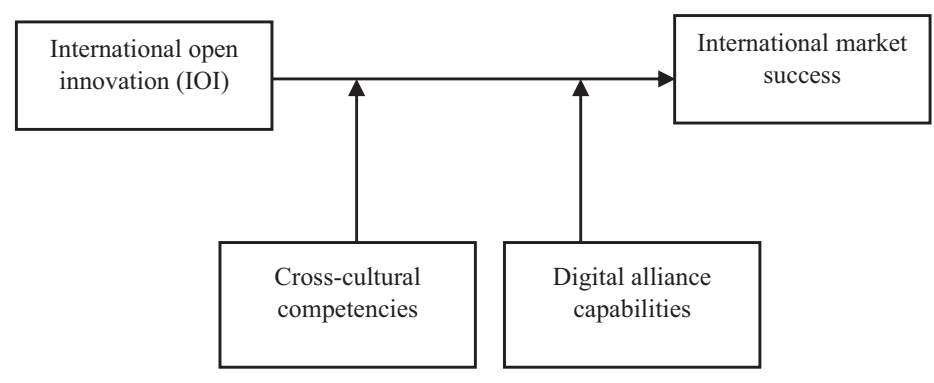


Second, IOI brings together partners from diverse geographic locations onto the same innovation platform (e.g. West, 2014); thus, these partners are able to realize and appreciate each other's concerns and to work together for mutual solutions (Kujala and Törnroos, 2018). The collective innovation efforts made by international alliance partners help them develop a common understanding of critical interdependencies where innovation is desired (Wang and $\mathrm{Hu}, 2020)$. Accordingly, IOI boosts the power and efficiency of jointly produced knowledge and innovations, besides accommodating dynamic market interests, thereby enabling the satisfaction of international market demands (Puthusserry et al., 2020). In synthesis, we formulated the following hypothesis:

\section{H1. IOI is positively related to ESME international market success.}

\subsection{The moderating role of cross-cultural competencies}

The extended RBV posits that the market success of international alliances is often a function of the implementation of effective knowledge-sharing routines aimed at transferring or creating specialized knowledge (Dyer and Singh, 1998; Dyer et al., 2018). This is particularly true in regard to the execution of complex tasks, such as those associated with IOI. In the context of international alliances, the transfer of knowledge for complex and novel OI activities may be hindered by cultural differences (Narooz and Child, 2017), which may present significant challenges to nurturing IOI (Jain et al., 2019; Oehme and Bort, 2015).

We argued that the expected positive relationship between IOI and international market success will be contingent on ESMEs having cross-cultural competencies, which refer to their management's possession of the set of skills, knowledge and traits required to work with people across different national cultures (Johnson et al., 2006). Those ESME managers who are equipped with cross-cultural competencies often possess cultural knowledge, cross-cultural sensitivity and communication abilities (Ferreras-Méndez et al., 2019), as well as the skills needed to adjust between cultural frames and apply cultural competencies during IOI activities (Liu et al., 2015). If equipped with an adequate pool of cross-cultural knowledge, managers can overcome any anxiety felt in relation to how individuals from different cultures will work and interact with each other (Nadeem et al., 2018). High levels of familiarity with different cultures can enhance the effectiveness of international alliances and information exchanges (Presbitero, 2020). In addition, behavioral flexibility can enable ESME managers to readily adjust and adapt to the needs of any given cultural context (Presbitero, 2021). Thus, we argued that, when ESMEs become involved in international activities and are able to conduct themselves appropriately in cross-cultural contexts, their IOI can be enhanced, thereby promoting their international market success. Specifically, high levels of cross-cultural competencies enable ESME managers to recognize cultural differences and react accordingly, thus giving positive impressions in IOI contexts to achieve international market success (Schneider and Engelen, 2015). Under conditions of low cross-cultural competencies, ESMEs may realize imperfect IOI gains, which can ultimately fail to meet international market demands. Thus, the interaction between higher cross-cultural competencies and IOI enables ESME managers to effectively transfer the knowledge and develop the innovation that may bring about international market success (Scuotto et al., 2020a). This is consistent with the extended RBV, which posits that ESMEs need knowledge-sharing routines (i.e. cross-cultural competencies) as a regular pattern of interaction in IOI activities, thus enabling the creation, sharing and recombination of knowledge for innovation, and leading to international market success (Dyer et al., 2018; Lavie, 2006).

Hence, this study contends that the greater the cross-cultural competencies possessed by managers, the greater the international market success that ESMEs can achieve through their engagement with IOI. By contrast, when an ESME's cross-cultural competencies are 
IMR

39,3

limited or poor, it accrues fewer benefits from its IOI for international market success. The above arguments led us to formulate the following hypothesis:

H2. Cross-cultural competencies moderate the effect of IOI on ESME international market success; the positive influence of IOI on international market success is increased by the presence of cross-cultural competencies.

\subsection{The moderating role of digital alliance capabilities}

Digital alliance capabilities relate to the exploitation of various ICTs "to purposefully create, extend, or modify the firm's resource base, augmented to include its alliance partners' resources" (Helfat et al., 2007, p. 66). According to the extended RBV, digital alliance capabilities comprise governance mechanisms that helps ESMEs to virtually monitor and manage IOI with their exchange partners (Dyer et al., 2018). Considering the momentum of the internet of things (IoTs), platforms and digital ecosystems - which are changing the nature of IOI (cf. West, 2014) - ESMEs can benefit from the international exchange of knowledge by building their digital alliance capabilities (Bereznoy et al., 2021; Santoro et al., 2018). Accordingly, this study draws from this logic to examine the potential moderating role played by digital alliance capabilities on the hypothesized relationship between IOI and international market success of ESMEs.

Given the smaller number of competitive resources they possess in comparison to large multinationals, ESMEs need to rely on IOI strategies to achieve international market success (Xiao et al., 2021). However, engaging with IOI and generating value through it can be challenging due to various relational ties, the differing needs of exchange partners, and not-invented-here attitudes and syndrome (e.g. Antons and Piller, 2015; Katz and Allen, 1982). Viewed as effective governance mechanisms, digital alliance capabilities promote the electronic processing of information and exchange of vital data to coordinate OI activities with dispersed international partners. Digital alliance capabilities are, thus, expected to enhance IOI effectiveness for international market success by reducing transaction costs and improving the internalization of any key knowledge originating from international network partners. Higher levels of digital alliance capabilities in information technology (IT)-enabled IOI activities can serve as a tool for relational contracts, reducing transactional costs and creating governance value through self-enforcing agreements (Kim et al., 2018). In addition, digital alliance capabilities, as a relationship-specific investment, favor the communication of critical information and enhance the mutual commitment of international partners toward OI (Bresciani et al., 2018), which ultimately enhances ESME international market success (Santoro et al., 2019). Therefore, this study drew insights from the extended RBV (Dyer and Singh, 1998) to argue that when ESMEs possess higher digital alliance capabilities, the benefits of IOI for international market success increase. The preceding discussion led us to posit the following hypothesis:

H3. Digital alliance capabilities moderate the effect of IOI on ESME international market success, i.e. the positive influence of IOI on international market success increases in the presence of high digital alliance capabilities.

\section{Research method}

\subsection{Sample and data collection}

The hypotheses of this study were tested on a sample of SMEs operating in the UAE. This context is particularly important for two reasons. First, the UAE is a fairly new EM in the Middle East with a rapidly evolving economy. The country has transformed itself from an underprivileged nation to a regional business hub and a top tourist destination (UAE, 2020). 
In recent years, the UAE has developed non-oil sectors to reduce its dependency on oil. This has led to the emergence of a large number of small firms in the manufacturing and service sectors. Second, SMEs based in the UAE are better positioned than others operating in similar markets. Their key advantages are because of local export and re-export facilities, with airports and ports linking 85 airlines and 120 shipping lines to over 130 destinations (Pervan et al., 2015). With this economic outlook, it has become imperative to study the IOI and international market success of ESMEs located in the UAE (which have been relatively under-researched) as it continues to diversify its economy (Nakos et al., 2019).

The study's sampling frame was drawn from the Commercial Directory of the Dubai Chamber of Commerce and Industry (DCCI, 2018-19). The selection criteria for our sample ESMEs were as follows: (1) being private and independent entities, not part of any bigger business group; (2) having less than 250 employees; (3) being engaged in international activities at least in the past three years; and (4) possessing international alliance experience for innovation activities. Following these selection criteria, 378 firms were identified to be included in our study. We conducted a survey with top managers (e.g. owners, chief executive officers (CEOs) and senior managers) from these ESMEs. To ensure the survey questionnaire's content and face validity, we conducted in-depth pilot interviews with four senior managers, during which they commented on the relevance and completeness of the questionnaire items. Based on their feedback, we revised the items to enhance the clarity and designed the final version of the questionnaire, which was administered in English, as the most common first or second language of most organizations in the UAE (Al Ariss and Guo, 2016).

The survey, which was conducted between February and June 2019, was distributed by means of a drop-off and collection technique (Aljifri and Khasharmeh, 2006; Elbanna and Fadol, 2016). In recent years, this data collection technique has gained popularity within EM contexts (Boso et al., 2019; Nakos et al., 2019), due to the declining response rates observed in mail and online surveys. The questionnaire was distributed to firms located in Dubai's Jebel Ali Free Zone, as this is one of the world's biggest free trade zones (Jafza, 2020). Ultimately, a total of 231 completed questionnaires were returned, providing a response rate of $61.11 \%$. The sample characteristics are summarized in Table 1.

\subsection{Measures}

The study constructs were assessed using multiple-item measures adopted from previous literature. We measured all items on a seven-point Likert scale. The details of the measures, reliability and validity assessments are provided in Table 2.

3.2.1 International open innovation. We defined IOI as the soliciting of ideas from and the sharing of internal intellectual property with international alliance partners (Chesbrough, 2006). Following previous studies (Cheng and Huizingh, 2014; Martinez-Conesa et al., 2017), we conceptualized IOI with two dimensions: inbound and outbound innovation. We measured inbound innovation with four items, and outbound innovation with three. Although we had adopted the items from previous studies (Cheng Colin and Shiu Eric, 2015; Popa et al., 2017), we had changed their wording reflect the international innovation context. A composite of the two dimensions constituted the variable score for IOI.

3.2.2 Cross-cultural competencies. Cross-cultural competencies are individual abilities to function effectively with people from different cultures (Johnson et al., 2006). We adapted and modified five items from Wang et al. (2014) to assess cultural adaptability in international alliances.

3.2.3 Digital alliance capabilities. Digital alliance capabilities refer to the abilities of ESMEs to manage international alliances using a wide range of ICTs (Nambisan et al., 2017; Urbinati et al., 2020). Digital alliance capabilities were measured along the three dimensions of 
IMR

39,3

Frequency (s)

Percentage (\%)

Industry

Biotechnology and pharmaceutical

22.9

ICT

Food and beverages

23.8

Construction and architecture

Entertainment and media

Retail and repairing services

Finance

Others

$\begin{array}{rr}53 & 22.9 \\ 55 & 23.8 \\ 31 & 13.4 \\ 26 & 11.3 \\ 25 & 10.8 \\ 13 & 5.6 \\ 8 & 3.5 \\ 20 & 8.7\end{array}$

International operations

Gulf Cooperation Council (GCC)

Middle East

Asia

Africa

Europe

13.4

11.3

10.8

5.6
3.5
8.7

8.7

USA

22.9

53

12.6

17.8

11.7

21.6

Job position

CEOs

13.4

Senior managers

$56.3 \%$

130

$43.7 \%$

Years served in firm

$0-5$

6-10

10-15

Over 15 years

$41.6 \%$

$28.3 \%$

Firm size

Less than 50

28

97

66

$18 \%$

50-100

101-250

$34.3 \%$

$304.5 \%$
89
$38.2 \%$

Firm age

$0-5$ years

$18.5 \%$

6-10 years

$28.3 \%$

11-15 years

Demographic

Over 15 years

alliance bonding, alliance coordination and alliance communications. Alliance bonding entails the ability to develop strong bonds with alliance partners by assigning them instrumental value through the use of ICT (Schreiner et al., 2009). Alliance coordination relates to an ESME's ability to align alliance tasks and arrange joint value mechanisms among alliance partners using ICT (Kandemir et al., 2006). Alliance communication refers to the sharing of meaningful and timely information using ICT between alliance partners. All three dimensions were measured using multi-items taken from past studies (Bresciani et al., 2018; Santoro et al., 2018; Schreiner et al., 2009; Shin, 2010).

3.2.4 International market success. International market success was measured over the previous three years by using five items (Musteen et al., 2010). These items assessed firm-level international market success relative to major competitors over the past three years [1] in terms of attainment of profitability goals, sales growth, market share growth, the introduction of new products and contribution of new products to overall profits (Millson, 2015; Zhong et al., 2013).

3.2.5 Control variables. We included several control variables such as size, age, type of industry and research and development (R\&D) intensity. Firm size was assessed through the 

suppliers, consultants, etc.) for knowledge and technology when developing innovations

Believe it is good to use international alliance partners (e.g. customers, competitors, suppliers, consultants, etc.) to complement our own R\&D own R\&D

International outbound practices $(C A=0.91 ; C R=0.91 ; A V E=0.77)$

Sells novel information and knowledge to international alliance partners

Offers royalty agreements to other international alliance partners to better benefit

Strengthens every possible use of our own intellectual properties to better benefit our firm*

Founds spin-offs to better benefit from our innovation efforts

Cross-cultural competencies $(C A=0.90 ; C R=0.89 ; A V E=0.62)$

Aware of the legal and economic systems of other countries

Conscious of the cultural knowledge in cross-cultural interactions

Evaluate the work of others in a culturally neutral way

Inspire information sharing among individuals who do not know each other and

\section{Digital alliance management}

Alliance bonding $(C A=0.90 ; C R=0.90 ; A V E=0.75)$

The use of ICT to

Signal readiness for discussion to our international alliance partners

Alliance coordination $(C A=0.91 ; C R=0.91 ; A V E=0.78)$

The use of ICT to

Maintain discussion forums with international alliance partners

Coordinate innovation plans with international alliance partners

Coordinate inventory levels with international alliance partners

Alliance communication $(C A=0.91 ; C R=0.92 ; A V E=0.74)$

The use of ICT to

To instantly link certain customer needs to our international alliance partners offering

International market success $(C A=0.92 ; C R=0.92 ; A V E=0.69)$

Profitability goals

Table 2. Constructs, measurement items and reliability and 
natural logarithm of the number of employees. Firm age was measured by the number of years since a firm had been founded. To control for industry, we included a dummy variable that discriminated between manufacturing and services. R\&D intensity was assessed as the ratio of R\&D employees to full-time employees.

\section{Data analysis and results}

\subsection{Potential bias testing}

To test for non-response bias, we compared the early and late respondent groups in terms of firm characteristics, such as firm size and firm age. The comparison of the two groups showed no significant differences $(p>0.05)$, thus suggesting that non-response bias had had no influence on our study results (Armstrong and Overton, 1977).

Furthermore, concerns about common method bias (CMB) could have arisen given the reliance on self-reported data from a single respondent for both the dependent and independent variables. Accordingly, we followed the statistical procedures suggested by prior research to determine whether CMB was present in our data (Chang et al., 2010; Podsakoff, 2003). Specifically, we performed a confirmatory factor analysis (CFA) in AMOS 26.0 and estimated three competing CFA models (Boso et al., 2013). Model 1 estimated a method-only model in which all the items were loaded on a single latent construct: $\chi^{2} / \mathrm{df}=9.37 ; \mathrm{CFI}=0.43 ; \mathrm{NFI}=0.41 ; \mathrm{RMSEA}=0.19 ; \mathrm{SRMR}=0.16$. Model 2 was a trait-only model in which each item was loaded on its respective latent construct: $\chi^{2} / \mathrm{df}=1.13$; $\mathrm{CFI}=0.99 ; \mathrm{NFI}=0.94 ; \mathrm{RMSEA}=0.02 ; \mathrm{SRMR}=0.04$. Finally, Model 3 was a method-andtrait model that involved the joint estimation of Models 1 and $2: \chi^{2} / \mathrm{df}=1.12$; $\mathrm{CFI}=0.99$; $\mathrm{NFI}=0.95 ; \mathrm{RMSEA}=0.02 ; \mathrm{SRMR}=0.04$. A comparison of the three models indicated that Models 2 and 3 were superior to Model 1, and that Model 3 was not substantially better than Model 2. Hence, this suggested that $\mathrm{CMB}$ was not a serious concern in our study.

Finally, to reduce the potential error with respect to retrospective data, we followed previous studies (e.g. Ju and Gao, 2017; Murray et al., 2011) and asked our respondents to concentrate on one major international market that was being served by their firm in responding to our survey. However, given the retrospective nature of the study, the existence of recall and current-attitude biases cannot be completely ruled out (Heidenreich et al., 2015).

\subsection{Reliability and validity of the measurement model}

To assess the reliability and validity of our multiple-item measures, we performed CFA using the maximum likelihood (ML) estimation method in AMOS 27.0. In line with previous recommendations (Bagozzi and Yi, 2012; Kline, 2015), we relied on the chi-square $\left(\chi^{2}\right)$ test and a number of heuristic fit indices to assess model fit. According to the psychometric literature, the normed chi-square should be ideally $<2.00, \mathrm{CFI} \geq 0.90, \mathrm{NFI} \geq 0.90, \mathrm{RMSEA} \leq 0.07$ and 
SRMR $\leq 0.07$ (Bagozzi and Yi, 2012). The results of the CFA model provided adequate fit for the data: $\chi^{2} / \mathrm{df}=1.13$; CFI $=0.99$; NFI $=0.94$; RMSEA $=0.02$; SRMR $=0.04$. As Table 2 shows, the factor loadings for each item were found to be positive and significant at $1 \%$, thus supporting the convergent validity of our measures.

Reliability was established by assessing Cronbach's alpha, composite reliability and average variance extracted (AVE) (Table 2). Cronbach's alpha and composite reliability values exceeded the respective recommended thresholds of 0.70 and 0.60 , respectively (Hair et al., 2017), thus confirming the reliability of our constructs. Furthermore, the AVE values for each construct exceeded the required benchmark of 0.50 , hence suggesting adequate construct convergent validity (Fornell and Larcker, 1981). We assessed discriminant validity by performing Fornell and Larcker's (1981) test to determine whether the square of the AVE for each construct exceeded the correlation of each pair of constructs. As displayed in Table 3, the square of the AVE for each construct was found to be greater than the inter-construct correlations; thus, we confirmed the discriminant validity of our study constructs.

\subsection{Hypotheses testing}

We performed a hierarchical regression analysis to examine the relationship between IOI and international market success, as well as the moderating effects of cross-cultural competencies and digital alliance capabilities. Hierarchical regression analysis is a technique that is appropriate not only to examine contextual-based models (Cohen et al., 2003), but also to evaluate the statistical differences in the total variance explained due to the next higher-order interactions (Wiklund and Shepherd, 2005). We mean-centered all the variables that were involved in interaction analysis. This exercise helped to reduce the occurrence of multicollinearity in our results. We calculated the variance inflation factors (VIF) to account for multicollinearity. The highest VIF value, which was found to be 1.90, was well below the recommended threshold of 10 (Aiken et al., 1991), thus indicating that multicollinearity was not an issue in our analysis. Table 4 provides the detailed results of our analysis. Model 1 is a baseline model aimed at estimating the effect of our control variables on international market success.

$\mathrm{H} 1$ proposed that IOI is positively related to international market success. As shown in Model 2 of Table 4, a positive and significant relationship was found between IOI and international market success $(\beta=0.25 ; p<0.001)$, providing support for $\mathrm{H} 1$. H2 predicted that cross-cultural competencies strengthen the relationship between IOI and international market success so that the relationship will be stronger for ESMEs with high cross-cultural competencies. Model 4 in Table 4 shows the interaction term between IOI and cross-cultural competencies (i.e. $\mathrm{IOI} \times \mathrm{CCC}$ ) to be positive and significant $(\beta=0.24 ; p<0.01$ ). Thus, $\mathrm{H} 2$ was found to be supported. H3 argued that international market success is maximized in the presence of high levels of both IOI and digital alliance capabilities. As shown in Model 6 of Table 4 , the interaction terms involving IOI and digital alliance capabilities (i.e. IOI $\times$ DAC) were found to be positive and significant $(\beta=0.16 ; p<0.05)$. In supporting $\mathrm{H} 3$, the results suggest that an alignment of high levels of IOI and digital alliance capabilities is associated with greater ESME international market success.

\subsection{Post hoc analysis}

To check the robustness of our findings, we conducted two additional analyses. First, we re-estimated our hypotheses using structural equation modeling (SEM) in AMOS 27.0. The results provided support for the relationship between IOI and international market success $(\beta=0.26 ; p<0.001)$ and for the moderating effects of cross-cultural competencies $(\beta=0.22 ; p<0.01)$ and digital alliance capabilities $(\beta=0.14 ; p<0.05)$. Furthermore, the fit
International open innovation for market success 
IMR

39,3

768

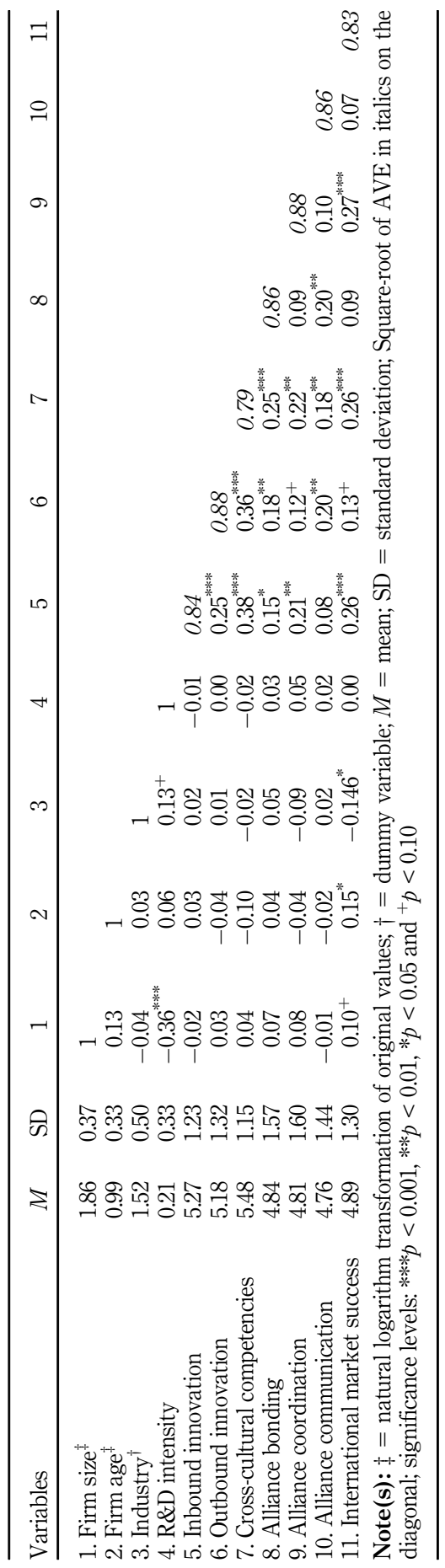

Table 3.

Descriptive statistics and correlations 


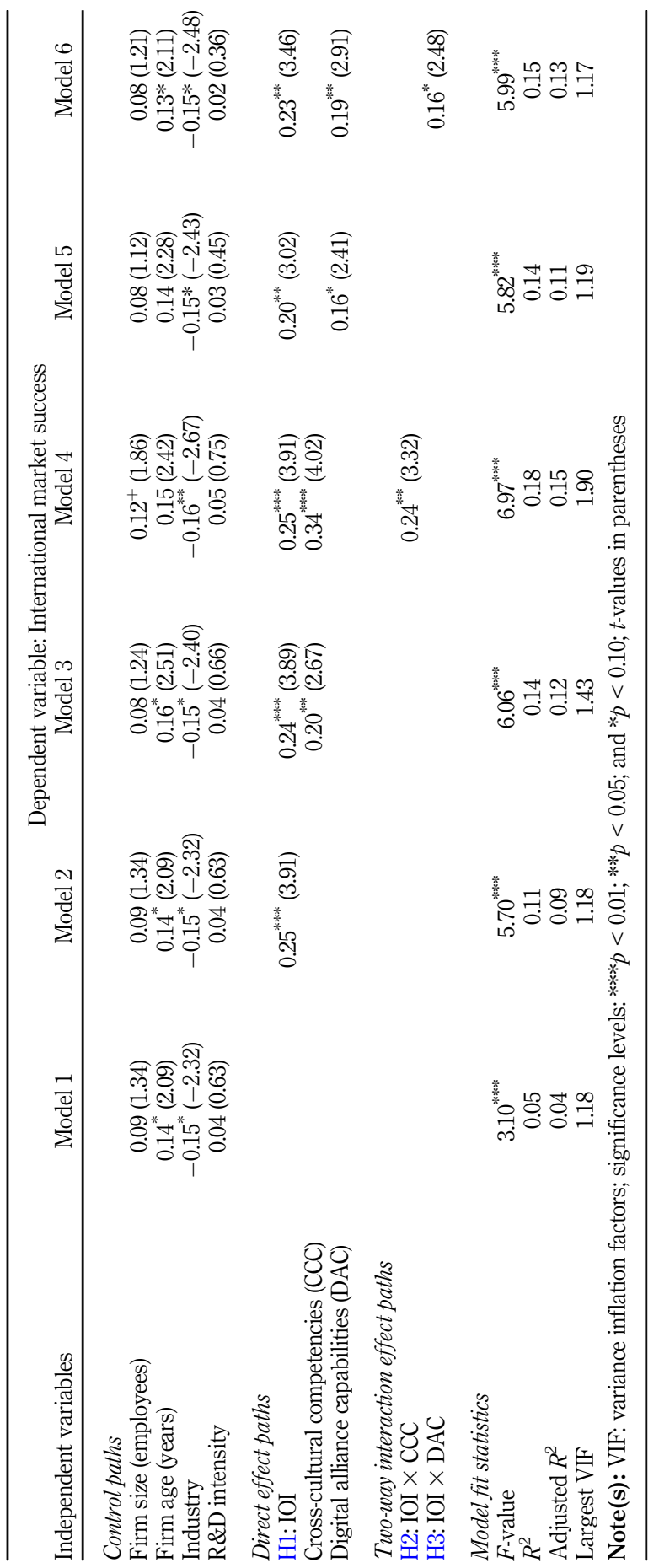


IMR

39,3

\section{0}

Figure 2.

Moderating effect of cross-cultural competencies on IOI and ESME international market success

Figure 3.

Moderating effect of digital alliance capabilities on IOI and ESME international market success indices for the structural model suggested good fit: $\chi^{2} / \mathrm{DF}=1.20 ; \mathrm{CFI}=0.99$; NFI $=0.96$; RMSEA $=0.04 ;$ SRMR $=0.03$.

Second, we estimated the hypothesized moderating mechanisms using the PROCESS macro (Hayes, 2017). Specifically, the study utilized Model 1 of the PROCESS macro with a $95 \%$ bias-correction confidence interval. The results suggested a significant main effect of IOI on international market success $(\beta=0.29 ; p<0.001)$ moderated by cross-cultural competencies $(\beta=0.38 ; p<0.001)$ so that the effect of IOI on international market success is stronger when ESMEs have a higher cross-cultural competency (effect $=0.36 ; p<0.001$; $\mathrm{LLCI}=0.15$ - ULCI $=0.57$ ), thereby supporting H2. Further, the results showed a significant moderating effect of digital alliance capabilities $(\beta=0.16 ; p<0.05)$ for the IOI-international market success relationship. Under conditions of high digital alliance capabilities, the effect of IOI on international market success was found to be positive and significant (effect $=0.46$; $p<0.001 ; \mathrm{LLCI}=0.23$; ULCI $=0.68$ ). Thus, we concluded that H3 was supported. To interpret the significance of the moderation effects, we followed previous practices (Aiken et al., 1991; Cohen et al., 2013) and plotted: (1) the moderating effect of cross-cultural competencies on IOI and international market success relationship and (2) the moderating effect of digital alliance capabilities on IOI and international market success relationship. The results are graphically presented in Figures 2 and 3.
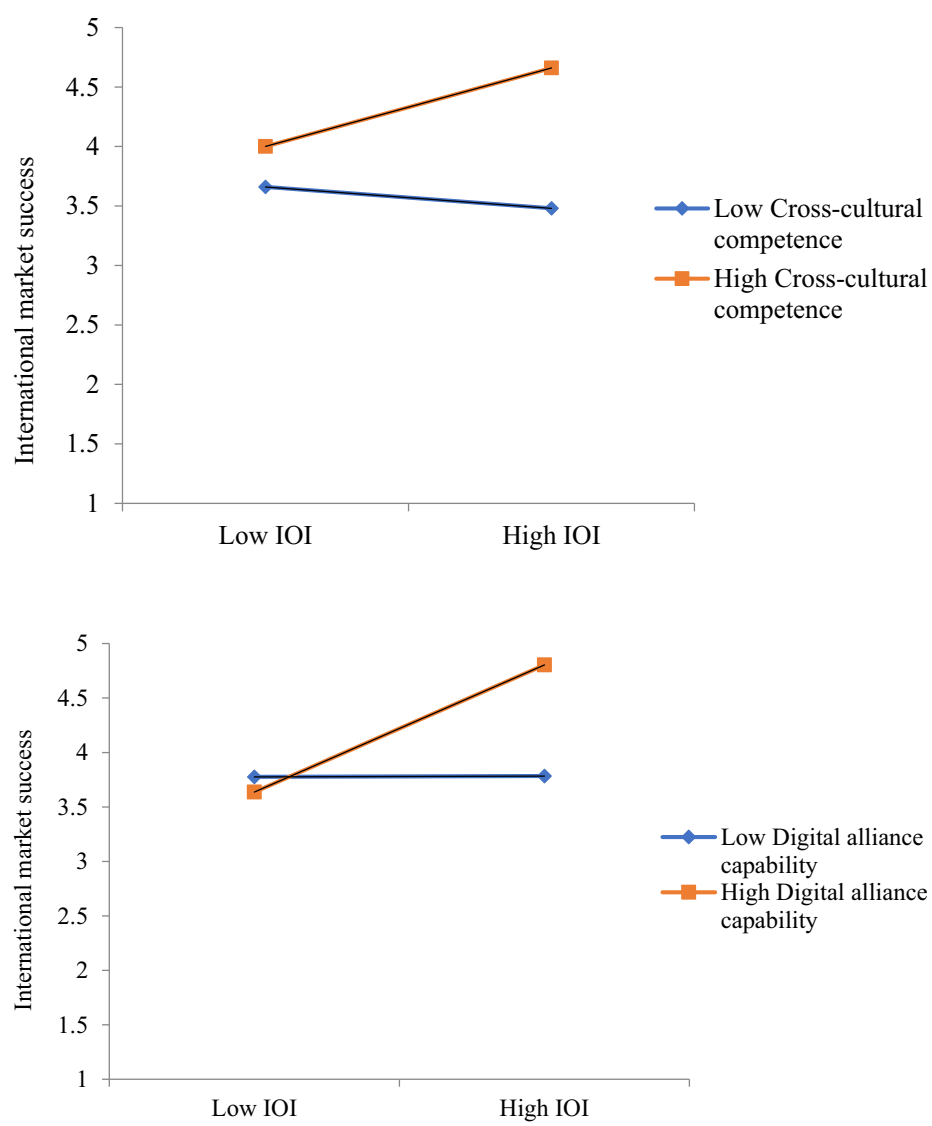


\section{Discussion and implications}

We sought to understand whether IOI has a positive impact on international market success and whether cross-cultural competencies and digital alliance capabilities moderate the baseline hypothesis. Specifically, we drew arguments from the extended RBV (Dyer and Singh, 1998) and international market literature and argued that ESMEs achieve international market success from IOI when they have high cross-cultural competencies. In addition, this paper contends that IOI leads to ESME international market success in the presence of strong digital alliance capabilities. Our results show that IOI has a positive relationship with international market success of ESMEs. While previous studies have extensively examined the implications of domestic OI for competitiveness (Leckel et al., 2020; Singh et al., 2019) and international market success (Santoro et al., 2019), ESMEs focusing on domestic OI may not have access to advanced and fine-grained knowledge, which is locally unavailable, thereby leading to limited knowledge base and resulting in a lack of novelty (Kapetaniou and Lee, 2019). As such, our findings confirm that IOI is indeed vital to access advanced knowledge and technology that are conducive to international market success of ESMEs. This is consistent with Brem and Nylund's (2021) argument, suggesting that IOI develops innovation in line with local culture and overcomes operating barriers, thereby leading to international market success. Also, this finding is in line with the extended RBV, which suggests that ESMEs' access to complementary partner resources is vital to gain competitive advantage in the dynamic marketplaces (Dyer et al., 2018). Given that ESMEs lack resources and market knowledge, IOI offers them a vital channel to develop their capabilities and enhance their international market success.

We also found that cross-cultural competencies moderate the impact of IOI on international market success of ESMEs. Specifically, the results suggest that, under conditions of high level of cross-cultural competencies, the effect of IOI on international market success is stronger. Previous studies indicate that different countries exhibit different characteristics and political environment, which require cross-cultural sensitivity and management (Cooke et al., 2018; Stoermer et al., 2021). To extend this line of research, our study confirms that in the presence of high level of cross-cultural competencies, ESMEs can exploit IOI to achieve high level of international market success.

Our results further indicate that digital alliance capabilities of ESMEs moderate the impact of IOI on their international market success. In the current context of the digital transformation, digitization has lowered the barriers into innovation activities for an unprecedented number of innovators worldwide (Bogers et al., 2017). In addition, scholars suggest that a wide range of digital systems can manage - or help to manage - their interaction with diverse alliance partners (He et al., 2020; Pagani and Pardo, 2017). Adding to this line of research, our findings confirm that digital alliance capability is a vital contingency factor to promote the impact of IOI on ESMEs' international market success. This finding is consistent with the extended RBV that suggests that effective governance of alliance using digital alliance capabilities is vital to utilize IOI for international market success (Dyer and Singh, 1998).

\subsection{Theoretical implications}

Our study contributes to the international marketing and innovation management literature in several ways. First, its findings differ from those of prior studies that were mainly focused on $\mathrm{OI}$ in domestic contexts. For example, recent research has found that external knowledge and internal innovation influence OI performance in domestic contexts (Hameed et al., 2021). Our study focused on OI in an international context, considering the role played by key skills (digital alliance capabilities and cross-cultural competencies), which had been ignored in former studies. Also, Cheah and Ho (2021) only considered the role played by outbound innovation in influencing commercialization performance. By leveraging both inbound and 
IMR

39,3

772

outbound forms of innovation, our study extends the theoretical boundaries of OI research and provides a new understanding of how firms can integrate their outbound and inbound innovation practices while maintaining their cross-cultural competencies and digital alliance capabilities.

Second, while previous research has indicated that international strategic alliances drive international market success (Kujala and Törnroos, 2018; Puthusserry et al., 2020), the theoretical specification and empirical examination of how IOI drives ESMEs international market success remain rather underexplored (Bhatti et al., 2021). We argued that IOI provides access to knowledge and innovation that ESMEs can exploit to achieve international market success. Our findings show that IOI has a material effect on international market success. In the context of UAE-based ESMEs, access to necessary resources is limited in the domestic market due to the limited institutional support for SMEs and the presence of increasing numbers of large multinationals (Nakos et al.,2019). Thus, ESMEs endowed with IOI are more likely to grow and succeed by achieving international market success while expanding in international markets.

Third, drawing insights from the extended RBV (Dyer and Singh, 1998), we argued that, although IOI may enable ESMEs to achieve international market success, such a relationship may be more or less influential depending on their possession of certain underpinning competencies and capabilities. Specifically, the results suggest that the effectiveness of IOI in promoting international market success is conditional on ESME cross-cultural competencies and digital alliance capabilities. The above-reported results show that IOI significantly and positively affects ESME international market success in the presence of greater cross-cultural competencies and digital alliance capabilities. This finding is particularly important in an EM context like that of the UAE, in which cross-cultural competencies and digital alliance capabilities help ESMEs to develop competitive advantages, which then aid the exploitation of IOI for international market success.

Finally, our empirical findings make an important contribution to OI literature focusing on ESMEs (Bhatti et al., 2021; Pervan et al., 2015). Moving beyond the domestic OI (Leckel et al., 2020), our study suggests that IOI enables global knowledge sourcing and a varied set of knowledge elements that are conducive to ESMEs' international market success (Kapetaniou and Lee, 2019). However, it is difficult for ESMEs to coordinate their innovation efforts with international partners (Xiao et al., 2021). In this regard, our study found that cross-cultural competencies and digital alliance capabilities act as effective governance mechanisms to effectively coordinate IOI activities and communicate with culturally distant partners. In this sense, this study contributes to existing OI research as, to the best of our knowledge, it is the first study that has developed and empirically tested an integrative research model to assess the effect of IOI on international market success as well as the moderating role of cross-cultural competencies and digital alliance capability. Such studies are also rare in the context of EMs' firms as these firms are rapidly expanding into foreign markets; thus, this study provides important insights on this topic in the context of SMEs originating from an EM.

\subsection{Practical and policy implications}

Beyond its theoretical ones, our study has important practical implications. First, its findings provide guidance suited to aid ESMEs in the UAE in improving their international market success utilizing IOI. In particular, our study shows that IOI is a vital determinant of international market success in the UAE setting. Whereas innovation capacity is generally low among ESMEs in the Middle East, it appears that UAE ESMEs pursue IOI to harvest interests in innovation and advanced technologies, which ultimately result in international market success. Thus, the managers of UAE ESMEs are advised to pay particular attention 
to investing in IOI to achieve competitive gains by developing international networks and alliances to benefit from fine-grained knowledge. Second, our study shows that cross-cultural competencies strengthen the positive effect of IOI on international market success. This, ESME managers should observe that the possession of higher cross-cultural competencies is advantageous when ESMEs need to exploit IOI. For example, when such competencies are available, ESMEs are motivated to become involved in IOI because they can easily understand the alliance tasks and effectively share information with culturally distant partners. These findings are important for ESMEs in developing and emerging countries, such as the UAE, given their lack of resources and institutional support, compared to developed markets. Third, our findings suggest that digital alliance capabilities moderate the impact of IOI on international market success. Therefore, ESMEs need to invest in the development of such capabilities, which can help managers to virtually govern their alliance tasks, digitally communicate with international partners and promote mutual learning activities. By doing so, ESMEs can generate higher returns from IOI in terms of international market success. The findings also provide EM policy makers with vital and useful insights. As EM policy makers are keen to develop their economies - and that the internationalization of small firms is among their most important policy agenda items - they need to provide institutional support and expose small firms to international networks, such as trade fairs and research institutes, to enable such firms to leverage international networks of knowledge and develop their capabilities for a rapid internationalization. Policy makers could also provide special incentives, such as vouchers for innovation, to small firms that are rapidly expanding into foreign markets and utilizing international sources of knowledge. Furthermore, policy makers should support small firms by identifying international sources of knowledge and innovation and by connecting rapidly internationalizing firms to the related networks.

\section{Limitations and future research directions}

Despite its contributions, our study has several limitations that offer avenues for future research. First, we did not consider the individual-level factors that may affect the IOIinternational market success nexus. For instance, the characteristics of individuals, such as entrepreneurial alertness (Tang et al., 2012), ambiguity tolerance (Begley and Boyd, 1987) or entrepreneurial passion (Chen et al., 2009) may moderate the direct hypothesized path. Thus, we would recommend that future research consider the moderating role played by these factors. Future studies could divide discriminate between inbound and outbound OI to explore their effects on international market success. Another possible setting for further research could be the business-to-business context. Second, we relied on self-reported measures, requiring our respondents to provide information about past events, which often suffers from retrospective bias. Thus, future research could utilize secondary and longitudinal data to overcome this bias. Third, the empirical context of our study was the UAE; therefore, our findings should be interpreted in the context of other EMs. Although the $\mathrm{UAE}$ is a unique empirical context, other EMs - like Pakistan, India and Indonesia - may have unique contextual (specifically, institutional) conditions that could offer additional insights for practice and theory development. Accordingly, scholarly attention could be devoted to exploring these relationships from the perspective of other developing and emerging countries. Third, future studies could pay more attention to the type of knowledge being transferred through international networks and to how SMEs based in EMs internalize that knowledge to improve their international performance. Fourth, intermediaries can play a vital role in IOI; therefore, future studies could examine such role and how intermediaries facilitate IOI networks and strategies. There is a scope to examine both the success- and failure-related factors of IOI across different types of SMEs. Fifth, future studies could pay 
IMR

39,3

\section{4}

more attention to the way firms develop their internal cultures for OI and whether domestic and international sources of knowledge provide equal opportunities to all types of firms. Future studies could also explore how firms develop a more central position in a given network to get fine-grained knowledge and develop different types of innovation. Finally, future studies could specifically analyze the role played by governments in relation to IOI and ESME performance (including market success).

\section{Conclusion}

We proposed a link between IOI and ESME international market success. Furthermore, we argued that the link between IOI and ESME international market success would be moderated by cross-cultural competencies and digital alliance capabilities. Our findings suggest a significant and positive relationship between IOI and international market success, and also show that both cross-cultural competencies and digital alliance capabilities positively moderate such relationship. Overall, our study contributes to the international marketing and innovation management literature by illustrating the specific conditions under which IOI leads to the international market success of ESMEs.

\section{Note}

1. A three-year period was used to assess ESME international market success following prior international studies (He and Wei, 2011; Xiao et al., 2021). This application indicates sustained success as it can balance the short-term fluctuations of ESME international market success (Gerschewski et al., 2015).

\section{References}

Abdelbadie, R.A. and Salama, A. (2019), "Corporate governance and financial stability in US banks: do indirect interlocks matter?", Journal of Business Research, Vol. 104, pp. 85-105.

Aiken, L.S., West, S.G. and Reno, R.R. (1991), Multiple Regression: Testing and Interpreting Interactions, Sage, Thousand Oaks, CA.

Al Ariss, A. and Guo, G.C. (2016), "Job allocations as cultural sorting in a culturally diverse organizational context”, International Business Review, Vol. 25 No. 2, pp. 579-588.

Albats, E., Alexander, A., Mahdad, M., Miller, K. and Post, G. (2020), "Stakeholder management in SME open innovation: interdependences and strategic actions", Journal of Business Research, Vol. 119, pp. 291-301.

Aljifri, K. and Khasharmeh, H. (2006), "An investigation into the suitability of the international accounting standards to the United Arab Emirates environment", International Business Review, Vol. 15 No. 5, pp. 505-526.

Almeida, P. and Kogut, B. (1999), "Localization of knowledge and the mobility of engineers in regional networks", Management Science, Vol. 45 No. 7, pp. 905-917.

Amit, R. and Schoemaker, P.J.H. (1993), "Strategic assets and organizational rent", Strategic Management Journal, Vol. 14 No. 1, pp. 33-46.

Antons, D. and Piller, F.T. (2015), “Opening the black box of 'not invented here': attitudes, decision biases, and behavioral consequences", Academy of Management Perspectives, Vol. 29 No. 2, pp. 193-217.

Armstrong, J.S. and Overton, T.S. (1977), "Estimating nonresponse bias in mail surveys", Journal of Marketing Research, Vol. 14 No. 3, pp. 396-402.

Arya, B. and Zhiang, L. (2007), "Understanding collaboration outcomes from an extended resourcebased view perspective: the roles of organizational characteristics, partner attributes, and network structures", Journal of Management, Vol. 33 No. 5, pp. 697-723. 
Bagozzi, R.P. and Yi, Y. (2012), "Specification, evaluation, and interpretation of structural equation models", Journal of the Academy of Marketing Science, Vol. 40 No. 1, pp. 8-34.

Barkema, H.G., Bell, J.H.J. and Pennings, J.M. (1996), "Foreign entry, cultural barriers and learning", Strategic Management Journal, Vol. 17 No. 2, pp. 151-166.

Barney, J. (1991), "Firm resources and sustained competitive advantage", Journal of Management, Vol. 17 No. 1, pp. 99-120.

Basuil, D.A. and Datta, D.K. (2015), "Effects of industry- and region-specific acquisition experience on value creation in cross-border acquisitions: the moderating role of cultural similarity", Journal of Management Studies, Vol. 52 No. 6, pp. 766-795.

Begley, T.M. and Boyd, D.P. (1987), "Psychological characteristics associated with performance in entrepreneurial firms and smaller businesses”, Journal of Business Venturing, Vol. 2 No. 1, pp. 79-93.

Bellantuono, N., Pontrandolfo, P. and Scozzi, B. (2013), "Different practices for open innovation: a context-based approach", Journal of Knowledge Management, Vol. 17 No. 4, pp. 558-568.

Bereznoy, A., Meissner, D. and Scuotto, V. (2021), "The intertwining of knowledge sharing and creation in the digital platform based ecosystem. A conceptual study on the lens of the open innovation approach", Journal of Knowledge Management, Vol. ahead-of-print No. ahead-ofprint, doi: 10.1108/JKM-10-2020-0769.

Bhatti, S.H., Santoro, G., Sarwar, A. and Pellicelli, A.C. (2021), "Internal and external antecedents of open innovation adoption in IT organisations: insights from an emerging market", Journal of Knowledge Management, Vol. 25 No. 7, pp. 1726-1744.

Bogers, M., Zobel, A.K., Afuah, A., Almirall, E., Brunswicker, S., Dahlander, L., Frederiksen, L., Gawer, A., Gruber, M., Haefliger, S., Hagedoorn, J., Hilgers, D., Laursen, K., Magnusson, M.G., Majchrzak, A., McCarthy, I.P., Moeslein, K.M., Nambisan, S., Piller, F.T., Radziwon, A., RossiLamastra, C., Sims, J. and Ter Wal, A.L.J. (2017), "The open innovation research landscape: established perspectives and emerging themes across different levels of analysis", Industry and Innovation, Vol. 24 No. 1, pp. 8-40.

Boso, N., Story, V.M. and Cadogan, J.W. (2013), "Entrepreneurial orientation, market orientation, network ties, and performance: study of entrepreneurial firms in a developing economy", Journal of Business Venturing, Vol. 28 No. 6, pp. 708-727.

Boso, N., Adeleye, I., Donbesuur, F. and Gyensare, M. (2019), "Do entrepreneurs always benefit from business failure experience?”, Journal of Business Research, Vol. 98, pp. 370-379.

Brem, A. and Nylund, P.A. (2021), "Maneuvering the bumps in the new silk road: open innovation, technological complexity, dominant design, and the international impact of Chinese innovation”, R\&D Management, Vol. 51 No. 3, pp. 293-308.

Bresciani, S., Ferraris, A. and Del Giudice, M. (2018), "The management of organizational ambidexterity through alliances in a new context of analysis: Internet of Things (IoT) smart city projects", Technological Forecasting and Social Change, Vol. 136, pp. 331-338.

Carayannis, E. and Grigoroudis, E. (2014), "Linking innovation, productivity, and competitiveness: implications for policy and practice", The Journal of Technology Transfer, Vol. 39 No. 2, pp. 199-218.

Chang, S.-J., van Witteloostuijn, A. and Eden, L. (2010), "From the Editors: common method variance in international business research", Journal of International Business Studies, Vol. 41 No. 2, pp. 178-184.

Cheah, S.L. and Ho, Y.P. (2021), "Commercialization performance of outbound open innovation projects in public research organizations: the roles of innovation potential and organizational capabilities", Industrial Marketing Management, Elsevier, In Press.

Chen, X.P., Yao, X. and Kotha, S. (2009), "Entrepreneur passion and preparedness in business plan presentations: a persuasion analysis of venture capitalists' funding decisions", Academy of Management Journal, Vol. 52 No. 1, pp. 199-214. 
IMR

39,3

Cheng, C.C.J. and Huizingh, E.K.R.E. (2014), "When is open innovation beneficial? The role of strategic orientation”, Journal of Product Innovation Management, Vol. 31 No. 6, pp. 1235-1253.

Cheng Colin, C.J. and Shiu Eric, C. (2015), "The inconvenient truth of the relationship between open innovation activities and innovation performance", Management Decision, Vol. 53 No. 5, pp. 625-647.

Cherbib, J., Chebbi, H., Yahiaoui, D., Thrassou, A. and Sakka, G. (2021), "Digital technologies and learning within asymmetric alliances: the role of collaborative context", Journal of Business Research, Vol. 125, pp. 214-226.

Chesbrough, H.W. (2006), Open Innovation: the New Imperative for Creating and Profiting from Technology, Harvard Business Press, Massachusetts, MA.

Chesbrough, H. and Bogers, M. (2014), "Explicating open innovation: clarifying an emerging paradigm for understanding innovation", in Chesbrough, H., Vanhaverbeke, W. and West, J. (Eds), New Frontiers in Open Innovation, Oxford University Press, Oxford, pp. 3-28.

Chesbrough, H., Lettl, C. and Ritter, T. (2018), "Value creation and value capture in open innovation", Journal of Product Innovation Management, Vol. 35 No. 6, pp. 930-938.

Cohen, J., Cohen, P., West, S.G. and Aiken, L.S. (2003), Applied Multiple Regression/correlation Analysis for the Behavioral Sciences, Lawrence Erlbaum, New Jersey.

Cohen, J., Cohen, P., West, S.G. and Aiken, L.S. (2013), Applied Multiple Regression/correlation Analysis for the Behavioral Sciences, 3rd ed., Lawrence Erlbaum, New Jersey.

Cooke, F.L., Wu, G., Zhou, J., Zhong, C. and Wang, J. (2018), "Acquiring global footprints: internationalization strategy of Chinese multinational enterprises and human resource implications", Journal of Business Research, Vol. 93, pp. 184-201.

DCCI (2018-19), Dubai Commercial Directory, Dubai Chamber of Commerce and Industry, Dubai, available at: https://dcciinfo.ae/.

De Silva, M. and Wright, M. (2019), "Entrepreneurial co-creation: societal impact through open innovation”, R\&D Management, Vol. 49 No. 3, pp. 318-342.

Del Giudice, M., Arslan, A., Scuotto, V. and Caputo, F. (2017), "Influences of cognitive dimensions on the collaborative entry mode choice of small- and medium-sized enterprises", International Marketing Review, Vol. 34 No. 5, pp. 652-673.

Del Giudice, M., Scuotto, V., Garcia-Perez, A. and Messeni Petruzzelli, A. (2019), "Shifting wealth II in Chinese economy. The effect of the horizontal technology spillover for SMEs for international growth", Technological Forecasting and Social Change, Vol. 145, pp. 307-316.

Dyer, J.H. and Singh, H. (1998), "The relational view: cooperative strategy and sources of interorganizational competitive advantage”, Academy of Management Review, Vol. 23 No. 4, pp. 660-679.

Dyer, J.H., Singh, H. and Hesterly, W.S. (2018), "The relational view revisited: a dynamic perspective on value creation and value capture", Strategic Management Journal, Vol. 39 No. 12, pp. 3140-3162.

D’Angelo, A., Majocchi, A. and Buck, T. (2016), "External managers, family ownership and the scope of SME internationalization”, Journal of World Business, Vol. 51 No. 4, pp. 534-547.

Ebner, W., Leimeister, J.M. and Krcmar, H. (2009), "Community engineering for innovations: the ideas competition as a method to nurture a virtual community for innovations", R\&D Management, Vol. 39 No. 4, pp. 342-356.

Elbanna, S. and Fadol, Y. (2016), "An analysis of the comprehensive implementation of strategic plans in emerging economies: the United Arab Emirates as a case study", European Management Review, Vol. 13 No. 2, pp. 75-89.

Elia, S., Messeni Petruzzelli, A. and Piscitello, L. (2019), "The impact of cultural diversity on innovation performance of MNC subsidiaries in strategic alliances", Journal of Business Research, Vol. 98, pp. 204-213. 
Ferreras-Méndez, J.L., Fernández-Mesa, A. and Alegre, J. (2019), "Export performance in SMEs: the importance of external knowledge search strategies and absorptive capacity", Management International Review, Vol. 59 No. 3, pp. 413-437.

Fornell, C. and Larcker, D.F. (1981), "Structural equation models with unobservable variables and measurement error: algebra and statistics", Journal of Marketing Research, Vol. 18 No. 3, pp. 382-388.

Freixanet, J., Braojos, J., Rialp-Criado, A. and Rialp-Criado, J. (2020), "Does international entrepreneurial orientation foster innovation performance? The mediating role of social media and open innovation", The International Journal of Entrepreneurship and Innovation, Vol. 22 No. 1, pp. 33-44.

Genc, E., Dayan, M. and Genc, O.F. (2019), "The impact of SME internationalization on innovation: the mediating role of market and entrepreneurial orientation", Industrial Marketing Management, Vol. 82, pp. 253-264.

Gerschewski, S., Rose, E.L. and Lindsay, V.J. (2015), "Understanding the drivers of international performance for born global firms: an integrated perspective", Journal of World Business, Vol. 50 No. 3, pp. 558-575.

Gulati, R. (2007), Managing Network Resources: Alliances, Affiliations, and Other Relational Assets, Oxford University Press, Oxford.

Guo, Y. and Zheng, G. (2019), "How do firms upgrade capabilities for systemic catch-up in the open innovation context? A multiple-case study of three leading home appliance companies in China", Technological Forecasting and Social Change, Vol. 144, pp. 36-48.

Hair, J.F., Babin, B.J. and Krey, N. (2017), "Covariance-based structural equation modeling in the journal of advertising: review and recommendations", Journal of Advertising, Vol. 46 No. 1, pp. 163-177.

Hameed, W.U., Nisar, Q.A. and Wu, H.C. (2021), "Relationships between external knowledge, internal innovation, firms' open innovation performance, service innovation and business performance in the Pakistani hotel industry", International Journal of Hospitality Management, Vol. 92, p. 102745.

Hayes, A.F. (2017), Introduction to Mediation, Moderation, and Conditional Process Analysis: A Regression-Based Approach, Guilford Publications, New York, NY.

He, Q., Meadows, M., Angwin, D., Gomes, E. and Child, J. (2020), "Strategic alliance research in the era of digital transformation: perspectives on future research", British Journal of Management, Vol. 31 No. 3, pp. 589-617.

He, X. and Wei, Y. (2011), "Linking market orientation to international market selection and international performance", International Business Review, Vol. 20 No. 5, pp. 535-546.

Heidenreich, S., Mohr, A. and Puck, J. (2015), "Political strategies, entrepreneurial overconfidence and foreign direct investment in developing countries", Journal of World Business, Vol. 50 No. 4, pp. 793-803.

Helfat, C.E., Finkelstein, S., Mitchell, W., Peteraf, M., Singh, H. and Teece, D. (2007), Dynamic Capabilities: Understanding Strategic Change in Organizations, Blackwell, Hoboken, NJ.

Ireland, R.D., Hitt, M.A. and Vaidyanath, D. (2002), "Alliance management as a source of competitive advantage", Journal of Management, Vol. 28 No. 3, pp. 413-446.

Jafza (2020), About Us, Jebal Ali Free Zone, Dubai, available at: https:/jafza.ae/.

Jain, N.K., Pangarkar, N., Yuan, L. and Kumar, V. (2019), "Rapid internationalization of emerging market firms - the role of geographic diversity and added cultural distance", International Business Review, Vol. 28 No. 6, p. 101590.

Jasimuddin, S.M. and Naqshbandi, M.M. (2019), "Knowledge infrastructure capability, absorptive capacity and inbound open innovation: evidence from SMEs in France", Production Planning and Control, Vol. 30 No. 10, pp. 893-906. 
IMR

39,3

Johnson, J.P., Lenartowicz, T. and Apud, S. (2006), "Cross-cultural competence in international business: toward a definition and a model", Journal of International Business Studies, Vol. 37 No. 4, pp. 525-543.

Ju, M. and Gao, G.Y. (2017), "Relational governance and control mechanisms of export ventures: an examination across relationship length", Journal of International Marketing, Vol. 25 No. 2, pp. 72-87.

Kafouros, M.I. and Forsans, N. (2012), "The role of open innovation in emerging economies: do companies profit from the scientific knowledge of others?”, Journal of World Business, Vol. 47 No. 3, pp. 362-370.

Kamalaldin, A., Linde, L., Sjödin, D. and Parida, V. (2020), "Transforming provider-customer relationships in digital servitization: a relational view on digitalization”, Industrial Marketing Management, Vol. 89, pp. 306-325.

Kandemir, D., Yaprak, A. and Cavusgil, S.T. (2006), "Alliance orientation: conceptualization, measurement, and impact on market performance", Journal of the Academy of Marketing Science, Vol. 34 No. 3, pp. 324-340.

Kapetaniou, C. and Lee, S.H. (2019), "Geographical proximity and open innovation of SMEs in Cyprus", Small Business Economics, Vol. 52 No. 1, pp. 261-276.

Katz, R. and Allen, T.J. (1982), "Investigating the Not Invented Here (NIH) syndrome: a look at the performance, tenure, and communication patterns of 50 R\&D Project Groups", $R \& D$ Management, Vol. 12 No. 1, pp. 7-20.

Khan, Z. and Lew, Y.K. (2018), "Post-entry survival of developing economy international new ventures: a dynamic capability perspective”, International Business Review, Vol. 27 No. 1, pp. 149-160.

Khan, Z., Rao-Nicholson, R. and Tarba, S.Y. (2018), "Global networks as a mode of balance for exploratory innovations in a late liberalizing economy", Journal of World Business, Vol. 53 No. 3, pp. 392-402.

Kim, D., Jean, R.-J.B. and Sinkovics, R.R. (2018), "Drivers of virtual interfirm integration and its impact on performance in international customer-supplier relationships", Management International Review, Vol. 58 No. 3, pp. 495-522.

Kline, R.B. (2015), Principles and Practice of Structural Equation Modeling, Guilford Publications, New York, NY.

Kohtamäki, M., Rabetino, R. and Möller, K. (2018), “Alliance capabilities: a systematic review and future research directions”, Industrial Marketing Management, Vol. 68, pp. 188-201.

Kujala, I. and Törnroos, J.Å. (2018), "Internationalizing through networks from emerging to developed markets with a case study from Ghana to the USA", Industrial Marketing Management, Vol. 69, pp. 98-109.

Lavie, D. (2006), "The competitive advantage of interconnected firms: an extension of the resourcebased view", Academy of Management Review, Vol. 31 No. 3, pp. 638-658.

Lavie, D. and Miller, S.R. (2008), "Alliance Portfolio Internationalization and Firm Performance", Organization Science, Vol. 19 No. 4, pp. 623-646.

Leckel, A., Veilleux, S. and Dana, L.P. (2020), "Local Open Innovation: a means for public policy to increase collaboration for innovation in SMEs", Technological Forecasting and Social Change, Vol. 153, p. 119891.

Lee, S., Park, G., Yoon, B. and Park, J. (2010), "Open innovation in SMEs: an intermediated network model”, Research Policy, Vol. 39, pp. 290-300.

Li, J. and Kozhikode, R.K. (2009), "Developing new innovation models: shifts in the innovation landscapes in emerging economies and implications for global R\&D management", Journal of International Management, Vol. 15 No. 3, pp. 328-339. 
Li, E.L., Zhou, L. and Wu, A. (2017), "The supply-side of environmental sustainability and export performance: the role of knowledge integration and international buyer involvement", International Business Review, Vol. 26 No. 4, pp. 724-735.

Li, L., Li, D., Goerzen, A. and Shi, W. (2018), "What and how do SMEs gain by going international? A longitudinal investigation of financial and intellectual resource growth", Journal of World Business, Vol. 53 No. 6, pp. 817-834.

Liu, X., Gao, L., Lu, J. and Wei, Y. (2015), "The role of highly skilled migrants in the process of interfirm knowledge transfer across borders", Journal of World Business, Vol. 50 No. 1, pp. 56-68.

International open innovation for market success

López-Duarte, C., González-Loureiro, M., Vidal-Suárez, M.M. and González-Díaz, B. (2016), "International strategic alliances and national culture: mapping the field and developing a research agenda", Journal of World Business, Vol. 51 No. 4, pp. 511-524.

Mahoney, J.T. (2001), "A resource-based theory of sustainable rents", Journal of Management, Vol. 27 No. 6, pp. 651-660.

Martínez-Román, J.A., Gamero, J., Delgado-González, M.d. L. and Tamayo, J.A. (2019), "Innovativeness and internationalization in SMEs: an empirical analysis in European countries", Technological Forecasting and Social Change, Vol. 146, p. 119716.

Martinez-Conesa, I., Soto-Acosta, P. and Carayannis Elias, G. (2017), "On the path towards open innovation: assessing the role of knowledge management capability and environmental dynamism in SMEs", Journal of Knowledge Management, Vol. 21 No. 3, pp. 553-570.

Millson, M.R. (2015), "Exploring the Nonlinear Impact of Organizational Integration on New Product Market Success", Journal of Product Innovation Management, Vol. 32 No. 2, pp. 279-289.

Mortara, L. and Minshall, T. (2011), "How do large multinational companies implement open innovation?”, Technovation, Vol. 31 No. 10, pp. 586-597.

Murray, J.Y., Gao, G.Y. and Kotabe, M. (2011), "Market orientation and performance of export ventures: the process through marketing capabilities and competitive advantages", Journal of the Academy of Marketing Science, Vol. 39 No. 2, pp. 252-269.

Musteen, M., Francis, J. and Datta, D.K. (2010), "The influence of international networks on internationalization speed and performance: a study of Czech SMEs", Journal of World Business, Vol. 45 No. 3, pp. 197-205.

Musteen, M., Datta, D.K. and Butts, M.M. (2014), "Do international networks and foreign market knowledge facilitate SME internationalization? Evidence from the Czech Republic", Entrepreneurship Theory and Practice, Vol. 38 No. 4, pp. 749-774.

Nadeem, S., Raza, M., Kayani, N., Aziz, A. and Nayab, D. (2018), "Examining cross-cultural compatibility of high performance work practices", International Business Review, Vol. 27 No. 3, pp. 563-583.

Nakos, G., Dimitratos, P. and Elbanna, S. (2019), "The mediating role of alliances in the international market orientation-performance relationship of SMEs", International Business Review, Vol. 28 No. 3, pp. 603-612.

Nambisan, S., Lyytinen, K., Majchrzak, A. and Song, M. (2017), "Digital Innovation Management: reinventing innovation management research in a digital world", MIS Quarterly, Vol. 41 No. 1, pp. 223-238.

Naqshbandi, M.M. and Jasimuddin, S.M. (2018), "Knowledge-oriented leadership and open innovation: role of knowledge management capability in France-based multinationals", International Business Review, Vol. 27 No. 3, pp. 701-713.

Narooz, R. and Child, J. (2017), "Networking responses to different levels of institutional void: a comparison of internationalizing SMEs in Egypt and the UK", International Business Review, Vol. 28 No. 4, pp. 683-696.

Nordman, E.R. and Tolstoy, D. (2016), "The impact of opportunity connectedness on innovation in SMEs' foreign-market relationships", Technovation, Vols 57/58, pp. 47-57. 
IMR

39,3
Oehme, M. and Bort, S. (2015), "SME internationalization modes in the German biotechnology industry: the influence of imitation, network position, and international experience", Journal of International Business Studies, Vol. 46 No. 6, pp. 629-655.

Ojala, A. (2009), "Internationalization of knowledge-intensive SMEs: the role of network relationships in the entry to a psychically distant market", International Business Review, Vol. 18 No. 1, pp. 50-59.

Oldham, G.R. and Da Silva, N. (2015), "The impact of digital technology on the generation and implementation of creative ideas in the workplace", Computers in Human Behavior, Vol. 42, pp. 5-11.

Pagani, M. and Pardo, C. (2017), "The impact of digital technology on relationships in a business network", Industrial Marketing Management, Vol. 67, pp. 185-192.

Paul, J. and Rosado-Serrano, A. (2019), "Gradual Internationalization vs born-global/international new venture models: a review and research agenda”, International Marketing Review, Vol. 36 No. 6, pp. 830-858.

Peeters, C., Dehon, C. and Garcia-Prieto, P. (2015), "The attention stimulus of cultural differences in global services sourcing”, Journal of International Business Studies, Vol. 46 No. 2, pp. 241-251.

Pervan, S., Al-Ansaari, Y. and Xu, J. (2015), "Environmental determinants of open innovation in Dubai SMEs", Industrial Marketing Management, Vol. 50, pp. 60-68.

Podsakoff, N. (2003), "Common method biases in behavioral research: a critical review of the literature and recommended remedies”, Journal of Applied Psychology, Vol. 88 No. 5, pp. 879-903.

Popa, S., Soto-Acosta, P. and Martinez-Conesa, I. (2017), "Antecedents, moderators, and outcomes of innovation climate and open innovation: an empirical study in SMEs", Technological Forecasting and Social Change, Vol. 188, pp. 134-142.

Presbitero, A. (2020), "Foreign language skill, anxiety, cultural intelligence and individual task performance in global virtual teams: a cognitive perspective", Journal of International Management, Vol. 26 No. 2, p. 100729.

Presbitero, A. (2021), "Communication accommodation within global virtual team: the influence of cultural intelligence and the impact on interpersonal process effectiveness", Journal of International Management, Vol. 27 No. 1, p. 100809.

Puthusserry, P., Khan, Z., Knight, G. and Miller, K. (2020), "How do rapidly internationalizing SMEs learn? Exploring the link between network relationships, learning approaches and post-entry growth of rapidly internationalizing SMEs from emerging markets", Management International Review, Vol. 60 No. 4, pp. 515-542.

Radulovich, L., Javalgi Rajshekhar, G. and Scherer Robert, F. (2018), "Intangible resources influencing the international performance of professional service SMEs in an emerging market: evidence from India”, International Marketing Review, Vol. 35 No. 1, pp. 113-135.

Rahman, M., Uddin, M. and Lodorfos, G. (2017), "Barriers to enter in foreign markets: evidence from SMEs in emerging market", International Marketing Review, Vol. 34 No. 1, pp. 68-86.

Rauch, A., Rosenbusch, N., Unger, J. and Frese, M. (2016), "The effectiveness of cohesive and diversified networks: a meta-analysis", Journal of Business Research, Vol. 69 No. 2, pp. 554-568.

Romero-Martínez, A.M., García-Muiña, F.E. and Ghauri, P.N. (2017), "International inbound open innovation and international performance", Canadian Journal of Administrative Sciences, Vol. 34 No. 4, pp. 401-415.

Sandberg, S. (2014), "Experiential knowledge antecedents of the SME network node configuration in emerging market business networks", International Business Review, Vol. 23 No. 1, pp. 20-29.

Santoro, G., Vrontis, D., Thrassou, A. and Dezi, L. (2018), "The Internet of Things: building a knowledge management system for open innovation and knowledge management capacity", Technological Forecasting and Social Change, Vol. 136, pp. 347-354. 
Santoro, G., Mazzoleni, A., Quaglia, R. and Solima, L. (2019), "Does age matter? The impact of SMEs age on the relationship between knowledge sourcing strategy and internationalization", Journal of Business Research, Vol. 128, pp. 779-787.

Schneider, M. and Engelen, A. (2015), "Enemy or friend? The cultural impact of cross-functional behavior on the EO-performance link", Journal of World Business, Vol. 50 No. 3, pp. 439-453.

Schreiner, M., Kale, P. and Corsten, D. (2009), "What really is alliance management capability and how does it impact alliance outcomes and success?", Strategic Management Journal, Vol. 30 No. 13, pp. 1395-1419.

Scuotto, V., Beatrice, O., Valentina, C., Nicotra, M., Di Gioia, L. and Briamonte, F.M. (2020a), "Uncovering the micro-foundations of knowledge sharing in open innovation partnerships: an intention-based perspective of technology transfer", Technological Forecasting and Social Change, Vol. 152, p. 119906.

Scuotto, V., Del Giudice, M., Tarba, S., Petruzzelli, A.M. and Chang, V. (2020b), "International social SMEs in emerging countries: do governments support their international growth?", Journal of World Business, Vol. 55 No. 5, p. 100995.

Sheng, M.L. and Hartmann, N.N. (2019), "Impact of subsidiaries' cross-border knowledge tacitness shared and social capital on MNCs' explorative and exploitative innovation capability", Journal of International Management, Vol. 25 No. 4, p. 100705.

Shin, D.-H. (2010), "The effects of trust, security and privacy in social networking: a security-based approach to understand the pattern of adoption”, Interacting with Computers, Vol. 22 No. 5, pp. $428-438$.

Singh, S.K., Gupta, S., Busso, D. and Kamboj, S. (2019), "Top management knowledge value, knowledge sharing practices, open innovation and organizational performance", Journal of Business Research, Vol. 128, pp. 788-798.

Soto-Acosta, P., Popa, S. and Martinez-Conesa, I. (2018), "Information technology, knowledge management and environmental dynamism as drivers of innovation ambidexterity: a study in SMEs", Journal of Knowledge Management, Vol. 22 No. 4, pp. 824-849.

Stoermer, S., Davies, S. and Froese, F.J. (2021), "The influence of expatriate cultural intelligence on organizational embeddedness and knowledge sharing: the moderating effects of host country context", Journal of International Business Studies, Vol. 52 No. 3, pp. 432-453.

Sui, S. and Baum, M. (2014), "Internationalization strategy, firm resources and the survival of SMEs in the export market”, Journal of International Business Studies, Vol. 45 No. 7, pp. 821-841.

Tang, J., Kacmar, K.M. and Busenitz, L. (2012), "Entrepreneurial alertness in the pursuit of new opportunities", Journal of Business Venturing, Vol. 27 No. 1, pp. 77-94.

UAE (2013), "Why UAE: the unlimited opportunities, ministry of foreign trade publications", Abu Dhabi, available at: https://www.economy.gov.ae/Publications/Why $\% 20 \mathrm{UAE} \% 20$ - $\%$ 20English.pdf.

UAE (2020), “About the UAE economy”, available at: https:/u.ae/en/about-the-uae/economy.

Urbinati, A., Chiaroni, D., Chiesa, V. and Frattini, F. (2020), "The role of digital technologies in open innovation processes: an exploratory multiple case study analysis", R\&D Management, Vol. 50 No. 1, pp. 136-160.

Wang, C. and Hu, Q. (2020), "Knowledge sharing in supply chain networks: effects of collaborative innovation activities and capability on innovation performance", Technovation, Vols 94-95, p. 102010.

Wang, D., Feng, T., Freeman, S., Fan, D. and Zhu, C.J. (2014), "Unpacking the 'skill - cross-cultural competence' mechanisms: empirical evidence from Chinese expatriate managers", International Business Review, Vol. 23 No. 3, pp. 530-541.

Wang, S.L., Luo, Y., Lu, X., Sun, J. and Maksimov, V. (2014), "Autonomy delegation to foreign subsidiaries: an enabling mechanism for emerging-market multinationals", Journal of International Business Studies, Vol. 45 No. 2, pp. 111-130. 
IMR

39,3

782

West, J. (2014), "Challenges of funding open innovation platforms: lessons from Symbian Ltd", in Chesbrough, H., Vanhaverbeke, W. and West, J. (Eds), New Frontiers in Open Innovation, Oxford University Press, Oxford, pp. 71-93.

Wiklund, J. and Shepherd, D. (2005), "Entrepreneurial orientation and small business performance: a configurational approach", Journal of Business Venturing, Vol. 20 No. 1, pp. 71-91.

Xiao, S.S., Lew, Y.K. and Park, B.I. (2020), "International Network Searching, Learning, and Explorative Capability: small and Medium-sized Enterprises from China”, Management International Review, Vol. 60 No. 4, pp. 597-621.

Xiao, S., Lew, Y.K. and Park, B.I. (2021), "International new product development performance, entrepreneurial capability, and network in high-tech ventures", Journal of Business Research, Vol. 124, pp. 38-46.

Zhang, X., Ma, X., Wang, Y. and Wang, Y. (2014), "How can emerging market small and medium-sized enterprises maximise internationalisation benefits? The moderating effect of organisational flexibility", International Small Business Journal, Vol. 32 No. 6, pp. 667-692.

Zhong, W., Peng, J. and Liu, C. (2013), "Internationalization performance of Chinese multinational companies in the developed markets", Journal of Business Research, Vol. 66 No. 12, pp. 2479-2484.

\section{Corresponding author}

Ahmad Arslan can be contacted at: ahmad.arslan@oulu.fi

For instructions on how to order reprints of this article, please visit our website:

www.emeraldgrouppublishing.com/licensing/reprints.htm

Or contact us for further details: permissions@emeraldinsight.com 